\title{
技術・調査報告 イうンの水凟源を取り巻く課題こつして Challenges Imposed by Water Resource Management in Iran
}

†連絡先著者（Corresponding Author）E-mail : yamada-t29t@mlit.go.jp

1) 国土交通省水管理・国土保全局河川環境課

テ100-8918 東京都千代田区霞が関2-1-3

River Environment Division, Water and Disaster Management Bureau, Ministry of Land, Infrastructure, Transport and Tourism, 2-1-3 Kasumigaseki, Chiyoda-ku, Tokyo, 100-8918, Japan

イラン・イスラム共和国は中東の乾燥地帯及び半乾燥地域に位置している. 1968年以降の降水統計を見ると, イラ ン全国の年平均降水量の過去 50 年間平均は, 約 $248 \mathrm{~mm}$ である。しかしながら, 年平均降水量は減少傾向を示してお り, 年平均降水量の近 10 年平均は約 $220 \mathrm{~mm}$ と, $11 \%$ 程度減少している。これに伴い利用可能な水資源量も減少傾向 にある。一方人口は増加の一途をたどり，1950年頃には 3,000 万人を下回っていた人口が 2019 年現在では約 8,000 万 人を上回っている. 加えて, 都市化の進展や農業活動の活発化などにより水需要は著しく高まり, 年間の水資源量 のうち 86 \%を人間活動で使用しているなど, 高度の水ストレス状態となっている.この結果, 国内の様々な地域に おいて恒常河川が間欠河川へと変化し，また社会活動における水の不足を補うために地下水位が継続的に低下して いる.このように，イランに扔ける水資源の管理に関する問題は，将来的なイランの社会経済活動の安定性や持続 可能性に関わる非常に重要な問題となっている，本稿では，このようなイランの水資源管理が抱える課題について 述べる。

キーワード：イラン, 水資源, 渇水, 水インフラ整備, 地域紛争

\section{I 、はじめに}

イラン・イスラム共和国（以後,「イラン」と記 す）は，北部でカスピ海及び南部でペルシャ湾やオ マーン湾に面し，日本の約 4.4 倍にあたる広大な国 土をもち, 総人口 8,000 万人（2016年時点）を有す る中東の大国である。世界第4位の石油埋蔵量及び 第 1 位の天然ガス埋蔵量を誇る資源大国であること に加え, 農業分野でもピスタチオやサフランで世界 1 位の生産量を誇り, 人口 8,000 万人の主食となる小 麦を自給できる農業大国でもある。さらには，国産 車の生産を行いうる技術を有する工業国という顔も 持つ.

イランと聞けば, 多くの日本人が乾燥した灼熱の 大地を想像するだろうが, 雨も降れば雪もつもり, 首都テヘランで雪だるまを作ることもできる。長い 時間の中で磨き上げられた卓越した文化や伝統及び 歴史的遺産を有しており，その中には水資源の乏し い地域に適応するために発達した水利技術である力 ナートに関するものも存在する。古代より, シルク
ロードを介して日本とも繋り, 現在でも親日家が多 い国である。

本稿では, このようなイランが抱える社会的な課 題の一つである水資源管理について, JICA長期派遣 専門家としてイランで勤務した著者の経験を紹介す るものである.

\section{II．イランの水資源の現状}

\section{1. 降水の特徵及び水資源賦存量}

イラン国内の降水の地域的特徵としては, アルボ ルズ山脈以北のカスピ海沿岸域や, ザグロス山脈の 西部や南部側で年間 $1,000 \mathrm{~mm}$ を超える降水がある一 方, 中央部や東部は砂漠地帯であり年降水量が 100 $\mathrm{mm}$ に至らない地域が広がるなど, 水資源の地域的 偏在が著しい (図一1).

一方, 降水の季節的特徴としては, 冬季及び春季 に降水量が多く, その後, 夏季及び秋季にはほとん ど雨が降らず，水資源の季節的な偏在が大きい。こ 


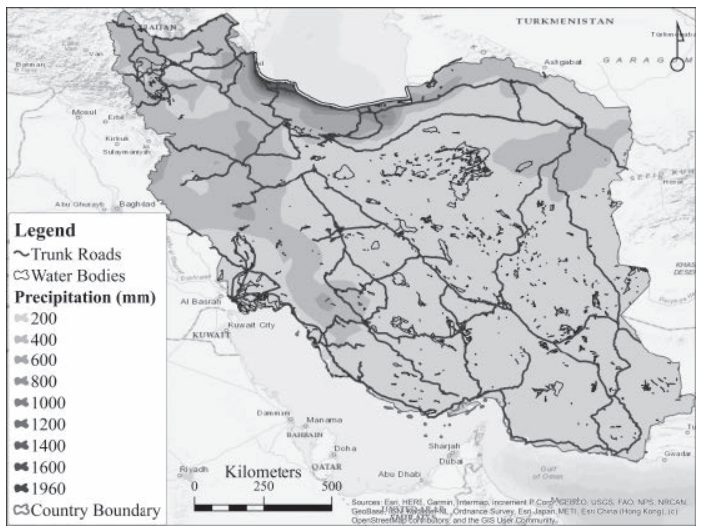

図 -1 イランの降水量分布

Fig. 1 Precipitation distribution in Iran.

のためイランでは, 水資源量の収支を考える期間と して，毎年9月 23 日から始まる 1 年間を水文年とし て統計を行っており，冬季及び春季の水資源をダム 等で貯留し, 降水の少ない夏季及び秋季に使用して いる(図一2).

1968 年以降の降水統計を見ると, イラン全国の年 平均降水量の過去 50 年間平均は, 約 $248 \mathrm{~mm}$ である. しかしながら, 年平均降水量は減少傾向を示してお り, 年平均降水量の近 10 年平均は約 $220 \mathrm{~mm}$ と, 11 \%程度減少している (図一3)。この降水量の減少に 伴い，また近年顕在化している平均気温の上昇もあ いまって, イラン国内の水資源賦存量（降水量から 蒸発散量を引いて当該地域の面積を乗じて求めた水 量）も経年的に減少している. 1968年〜 1998年まで の 30 年間の平均水資源賦存量が 1,250 億 $\mathrm{m}^{3}$ であるの に対し, 上記期間も含む過去 50 年平均水資源賦存量 は 1,160 億 $\mathrm{m}^{3}$, 近 17 年においては 880 億 $\mathrm{m}^{3}$ と推計さ れており，国内で利用可能な水資源が長期的に減少 傾向にあることを示している.

\section{2. イランの水資源の利用状況}

一方, イランの一年間の水資源使用量は, 凡そ 1,000 億 $\mathrm{m}^{3}$ 程度と推計されており，日本の年間水使 用量である799億 $\mathrm{m}^{3}$ (国土交通省水管理・国土保全 局水資源部, 2019）に比して非常に大きい.また, 過去 50 年平均水資源賦存量である 1,160 億 $\mathrm{m}^{3}$ と比較 すると, 1 年分の水資源賦存量の約 $86 \%$ に及ぶ水を 社会活動に使用している計算となり，水資源が極め てひっ迫している現状を示している. 残念ながら水 使用量の経年変化についてはデータを入手できてい

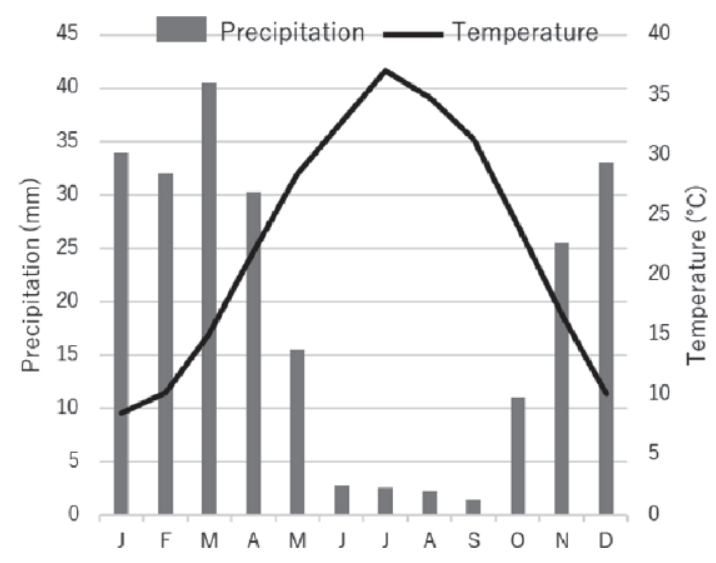

図－2 テへランにおける月降水量及び気温

Fig. 2 Monthly precipitation and temperature in Tehran.

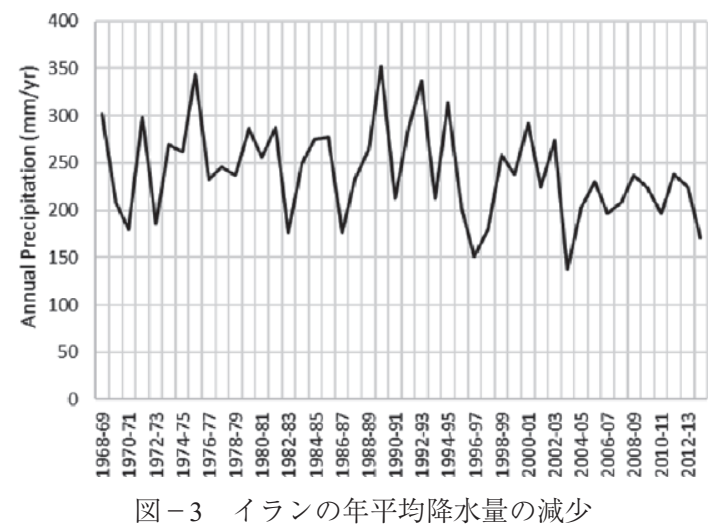

Fig. 3 Decline in annual precipitation in Iran.

ないが，過去の著しい人口増加（1960年代に人口が 3,000 万人程度であったが, 現在では 8,000 万人に達 している）を考慮すると, 水使用量も右肩上がりに 増加していることが推測される.

水使用量の内訳をみると, 約 400 億 $\mathrm{m}^{3}$ が表流水で あるのに対し, 約 600 億 $\mathrm{m}^{3}$ の水利用を地下水に依存 しており, 地下水への依存率が高い。 また, 全体の 水利用量のうち, 約 9 割を農業生産に利用し, 残りの 1 割を生活用水及び工業用水として使用しており，農 業分野における水使用量が格段に多いことがわかる.

さらに, 地下水の利用状況を井戸数の変化から考 察する. 2017 年時点で, イラン国内の総井戸数は 807,000 基とされており, 過去から著しく増加して きている (図一4). イランの地下水利用については, 水資源配分法（The Fair Water Distribution Law, 1983） に基づく許可制となっており，エネルギー省に属す る水資源管理公社の地方支分部局である各州に在す 
る地方水公社が許可事務を担うこととされている. しかしながら, 井戸の内訳をみると, およそ4割に あたる320,000基が無許可で設置されている（図一 5). イランでは, 地下水位の減少が著しい地域では, 地下水の新規利用を禁止する措置を行っている地域 が多数存在し，かつ，無許可井戸の取り締まりを実 施してきているが，現実的には無許可井戸は年間 10,000 基のペースで増加しており，行政による対応 が追い付かない状態となっている。

\section{1 人当たりの水使用量}

イランに拈ける 1 人当たりの水使用量については, 明確に調査された資料を見たことがないが，一般的

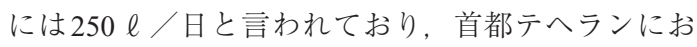

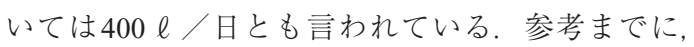
東京都水道局によると 2015 年の東京都の 1 人当たり の水使用量は $219 \ell /$ 日である.この水利用実態に 関するデータが限定されている一つの理由は, イラ ンの住居構造にあると思われる。 イランでは個別住 宅ではなく, マンションに複数世帯が入居して生活

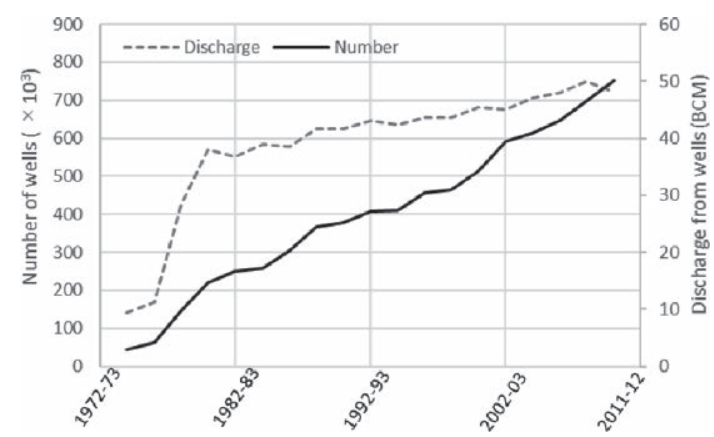

図 -4 イラン国内の総井戸数の変化

Fig. 4 Time variation of total number of wells in Iran.

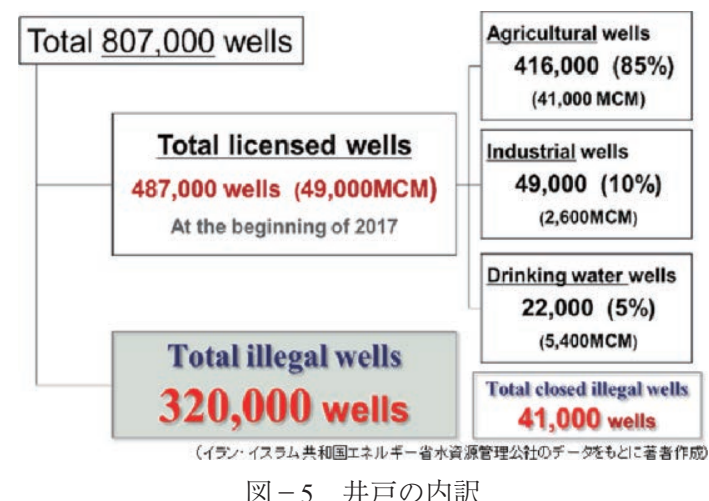

Fig. 5 Breakdown of Iranian wells.
する形態が通常である。しなしながら, マンション には水道メーターが1台しか設置されていないのが 一般的である。このため, 各入居者の水道料金は, マンション全体の水道料金の合計額を, 各入居者に 案分して支払う方法となっている。このため, 個別 居住者の水使用の実態が把握できないばかりでな く, 居住者 1 人が節水努力を行っても, その利益が 当該居住者のみに還元されないため, 節水のための 経済的動機付けが生じにくい一因となっていると推 測する。

\section{4. 水の所有権}

ここで，イランの水の所有権について述べる。 イ ラン・イスラム共和国憲法第 45 条において, 海洋, 湖沼, 河川及びその他の公共水域は政府が管理する と記載されている。ささらに, 水資源配分法第 1 条に おいてはより具体的に, 水が公有財産であり, 政府 の管理に属することが規定されている。次に, ダム 等により開発された水資源の配分については, 各州 に在する地方水公社が当該地域の農業用水, 生活用 水, 工業用水の必要量を算出して政府に提出し, 各 年の水資源の状況に応じて最終的に年毎の地域別及 び水利用分野別の配分量が決定されるという制度が とられている。このように, 資源である水を政府が 毎年, 地域毎及び分野毎に配分量を定めるという方 法が, 渇水時などにおいて地域住民の不公平感や不 満の種となる事例が生じている.

\section{5. 水の料金について}

水の料金については, 農業用水の料金は, 地表水及 び地下水に分けられる. 地表水については農業料金法 （Farming Water Fee Law, 1980）に基づき，前年度の収穫 高に対して, 灌溉用水の供給ネットワークの質により 定められた率（3％,2％,1％）を乗じた額とされて いる. 地下水料金については, 霜害及び渇水被害補償 法 (Law on Finance Allocation for Compensating Damages due to Drought and Frost,2004）に基づき，料金徴収が免 除され, 以降, 農業用水としての地下水利用について は無料とされている.

生活用水については, 各地域の状況に応じて定め られているが, 総じて水道料金が非常に安価に設定 されている. 2019年4月時点で, 全国の水道料金は およそ4,500-5,000 IRR / $\mathrm{m}^{3}$ 程度である。これは, 1 家庭が 1 月に $20 \mathrm{~m}^{3}$ の水を使用したと仮定した場合， 水道料金は約 100,000 IRR（2019年4月14日時点の 
市場レート 1 USD=137,500 IRRで約 0.7 USD）であ る。これに対し，その原価は水道料金の約 2 倍の 10,000 IR $/ \mathrm{m}^{3}$ 程度とされている。 な押，この「原 価」の内訳については定かではない。このように, 水道料金については社会保障の意味合いが強く, 日 本の水道事業のように水道料金を総括原価をもとに 定める考え方は適用されてない，大まかに言えば, 原価の半分を水道料金として徴収し, 残りの半分を 政府の補助金として賄っている状況であり, この補 助金額は，今年度予算で 334,200 億IRR（2019年4月 14 日時点の市場レート 1 USD $=137,500$ IRRで約 2.5 億USDに相当）程度である。このため，日常生活に おいて，各家庭で節水を進める経済的な動機付けが 生じず，水が多く使用されるほど政府の補助金の支 出額が増加する構造となっている。

工業用水については扮よそ2,500-3,000 IRR $/ \mathrm{m}^{3}$ 程度で販売されていると聞いているが，やはり安価 であるため，工場内で水を再利用するような経済的 動機付けにならず，日本の工場で行われる水の再生 利用技術の導入に対して積極的に踏み込めない点が あるものと推測される。

上述のように，イランに拈ける水の価格は安価で ある. 水は人間の生存及び生活水準に関わるため, その価格設定の考元方は国の社会保障の考え方に大 きく依るものと思料する。他方, 総量として水資源 量が少ないイランにおいては，節水に対する国民の 動機付けの意味も含め, 水料金の設定を検討する必 要があると考えられる。

\section{6. イラン国内の負の水収支}

上述のような状況のもと，イランでは水が日々使 用されている。現在の水資源の使用状況は，年間の 水資源賦存量で賄えるレベルを超えており，結果と してイラン全体の水収支は赤字となる状況が続いて いる，水資源管理公社の試算によれば，地上の水資 源から年間 6 億 $\mathrm{m}^{3}$, 地下水資源から年間 58 億 $\mathrm{m}^{3}(50$ 億 $\mathrm{m}^{3}$ という試算もある）が減少し続けているとされ ている。これを要因として，第4章で述べる様々な 課題が発生することとなるのである。

\section{III. イランにおける水インフラの整備状況}

\section{1. 上下水道施設の整備状況}

次に，イランに抢ける水関係のインフラ整備の現 状として, 上水道施設及び下水道施設の整備状況を
説明する．まず, 2017 年時点における上水道施設の 普及率は, 都市部では $99 \%$, 地方部では $80 \%$ に達 している。一方, 下水道網への接続率は, 都市部で は46\%，地方部では $0.4 \%$ と依然として十分整備が 進んでいない状況である（図一6）。都市部と地方部 という区分であるが，エネルギー省のもとで水道供 給及び下水処理を担う水道・下水道技術公社の地方 支分部局として，全31州に，都市部の上下水道整備 を担う公社（計36社）と, 地方部を担う公社（31 社）があり，それらの管轄範囲による区分となって いる.このように水道施設の整備率は高いものの, 下水道の整備はいまだ道半ばの状態が続いている. イランでは伝統的に, 污水を地下浸透させて処理し てきている。近年では，マンションに居住するス夕 イルが一般的であるが，下水処理方法としては依然 としてマンションの底部から地下へ浸透させて処理 する方式がとられている場合が多い，常に乾燥して いる気候のためか，下水の臭気が気になることもほ とんどない，近年になり下水道網の整備が急速に進 められているが, 2015 年 12 月時点では, 最終的に下 水処理プラントまで接続している率は, 総人口の $22.4 \%$ \%゙あ。

イランの主要都市の上水施設の無収水率は, イラ ン国内の多くの主要都市に扔いて扮よそ20３0％ 程度とされている。 なお，この無収水率については 主として管路等からの漏水によるものか, メーター 不感等の要因によるものかの詳しい分析は把握でき ていない.いずれにしろ，水道サービスを持続可能 に実施していくためには, 水道施設のアセットマネ ジメントの考え方が重要であることから，水料金の 検討を含め, 適切な維持管理及び更新の体制が必要 となってくると思われる。また，イラン主要都市に

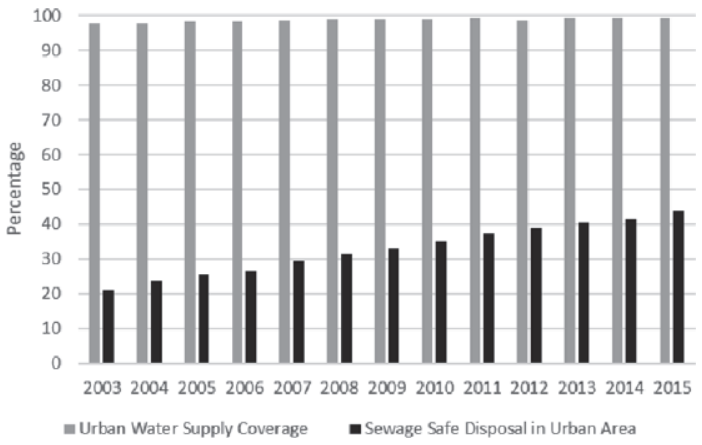

図 - 6 上水道及び下水道の整備状況

Fig. 6 Coverage ratio of water supply and wastewater collection network. 
おける下水道網への接続率は地域間の整備格差が大 きく, 2015 年時点で, 首都テへランにおいても下水 道網への接続率は 4 割程度にすぎない

\section{2. ダムの整備状況}

新たな水資源開発のため, イランでは近年, 積極 的にダム建設が行われてきた. 2017 年 11 月時点にお ける水資源管理公社統計デー夕によると，運用中の ダム（逆調整ダム含む）は 173 基であり，その総貯 水容量は約 517 億 $\mathrm{m}^{3}$ である。これは日本のダムの総 貯水容量の 2 倍以上の容量規模であり, 日本のダム に比べて個々のダムが大きな貯水容量を持ってい る. ダム開発の主要な目的は灌溉用水及び生活用水 の確保であるが，3番目に多い目的が環境用水確保で ある点は興味深い。また, ダム形式については, 約 49 \%がアースダム, 約 26 \%がロックフィルダムで ある。

一方, 計画段階もしくは建設途中のダムは76基で ある。ただし，近年，ダム建設による環境影響など を踏まえてダム計画の見直しがあり，またダム建設 に対する世論が悠しさを増しており，実際に建設さ れるか否かは不明である。

\section{IV．イランの水資源の様々な課題}

\section{1. 地表水及び地下水資源の減少とその影響}

イラン国内の負の水収支は，地表水及び地下水の 減少として表面化している，イスファハン市を貫流 するザヤンデルード川は, 周辺地域の約 500 万人へ 飲料水を供給し，また農業用水として利用される河 川である。ザヤンデルード川はもともと恒常河川で あるが降雨量の減少や流域開発により，イスファハ ン市街地上流に位置する取水施設より下流部につい ては, 2000 年頃を境に年に $3 \sim 4$ か月程度干上がる間 欠河川となり，現在では一年中干上がる状態が続い ている，市街地の河川周辺は緑地として整備されて いるが, 河川の中には生物の気配はない（写真一1）. 同様に, フーゼスタン州等を流れるカルーン川はイ ラン国内で最も水量が豊富で舟運可能な河川である が, 降雨量の減少や流域開発により, 流量が次第に 減少してきている.

これら河川流量の減少は, さらに湿地の乾燥化を 引き起こしている，イラン内陸部の河川は，最終的 に海まで流達することなく, 内陸部で湿地を形成し て完結する場合が多い。これらの湿地は動植物の生
息地として良好な環境を維持してきた。しかしなが ら河川流量の減少は湿地を乾燥させ, 動植物の生息 環境を減少させてきている。湿地環境に関する詳細 なデー夕は未確認であるが，報道によると既に 60 \%近い湿地が乾地化しているという情報もある。

次に地下水については, イラン国内の各地で, 継 続して地下水位が低下している. 図一7はエネルギー 省が作成した，全国及びレベル 1 流域内の地下水観 測により得られた 1 年間の地下水位低下量の平均値 を示している（図一7）。年間の地下水位低下量は地 域により差があるが, 過去の観測デー夕も含めて全 国平均すると，年間約 $50 \mathrm{~cm}$ 地下水位が低下してい ることを示している。 また, 水資源管理公社のデー 夕によると, これらの地下水位低下により全国に 487,000 基ある許可井戸のうち, 1 年間に深掘り申請 が行われる井戸が全体の約 4 \%あり, また, 同一敷 地内への井戸移設申請が行われる井戸も全体の $4 \%$ 存在する. 1 年間あたり, 許可井戸全体の約 $8 \%$ に当

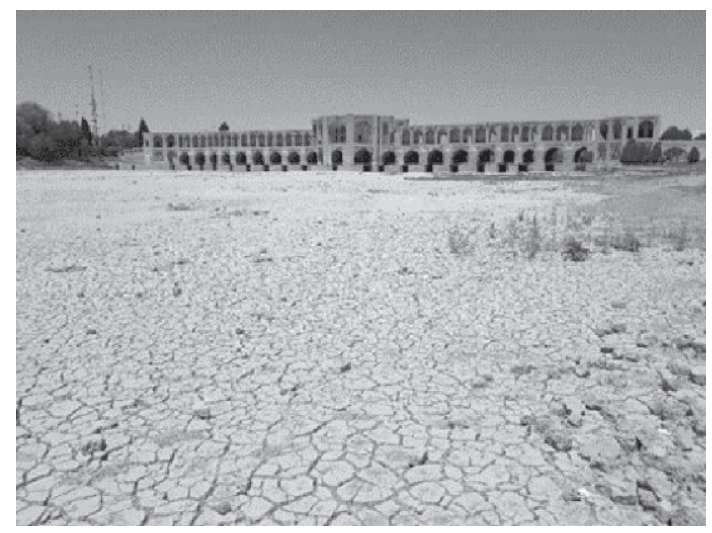

写真-1 干上がったザヤンデルード川とハージュ橋

Photo. 1 Zayandehrud river and Khaju bridge.

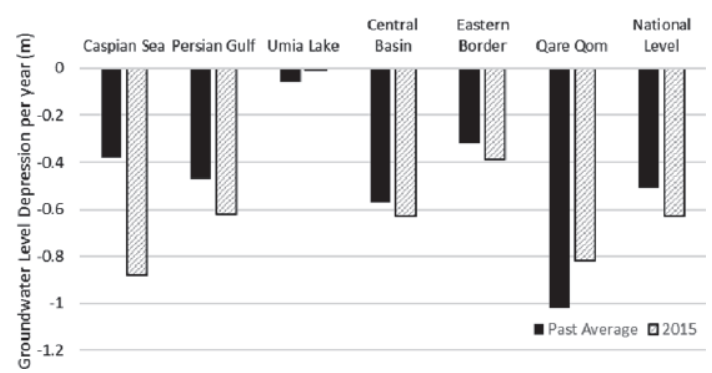

図 -7 イラン全国平均及びレベル 1 流域毎の年間地下 水位低下量

Fig. 7 Annual average decline of groundwater level in each level-1 basin. 
たる約 40,000 井戸が地下水位低下のために何らかの 対策を行う必要性が生じているということとなり, 農業生産コストの増加が懸念される。

\section{2. 水に関する地域間の紛争及び農民デモ}

さらに, このような状況が地域間の紛争や現状に 対する農民の不満を増加させる一因となっている. 2017 年 9 月 23 日 2018年 9 月 22 日のイラン水文年 は，全国的に過去 50 年間の水文観測史上最悪の渴水 状況を呈していた，幸いにも5月の降雨により状況 は一定程度改善されたものの, 農業用水の供給が停 止されたり，イラン国内の米作を一部地域のみに限 定するなど，農民にとっては非常に厳しい状況が続 いていたこのような状況下，各地では政府の水資 源に関する管理方法を非難する農民による抗議が発 生した.

なかでも，ザヤンデルード川の水資源をめぐる 3 州に跨る水問題は, イランの水資源管理の困難さを 象徵する代表的な事例であり，ここに紹介する。

ザヤンデルード川は，上流域がチャハールマハー ル・バクティアリ州を流れ，中流部と下流部がイス ファハン州を貫流し，かつ下流の流域のごく一部が ヤズド州に位置する 3 州に跨る河川延長 $405 \mathrm{~km}$ の河 川である，当該流域の水瓶であるザヤンデルードダ ムは1966年に建設が開始され1970年に完成以降, 地域住民の飲料水や農業・工業用水の供給, 水力発 電に利用されている。ザヤンデルード川の水資源は, 当該流域上流部に降る降雨に加えて，チャハールマ ハール・バクティアリ州を流れるイラン随一の水量 を誇るカルーン川の水を流域間導水して賄われてい る。この導水は, 1954 年完成の第1クーラントンネ ル以降, 1985年の第2クーラントンネル, 2006年の チェシュメ・ランガントンネル完成と, 順次拡大さ れてきている.

一方，ザヤンデルード川の水は，イスファハン州 に隣接するヤズド市民の飲料水としても提供されて いる。 ヤズド市の地下水は水質が悪く飲用に適さな いことから，政府は1989年にザヤンデルード川の水 をヤズド市に導水することを決定し，1999年より導 水を開始している。しかしながら, 2000 年以降，ザ ヤンデルード川の流況が次第に悪化し，イスファハ ン市街の河道が干上がり，またザヤンデルード川下 流域の農民が農業用水を確保できない事態が生じて くると，特に下流部の農民の間でヤズド市への導水 に対する不満がたまり，たびたび農民の抗議活動が
発生するようになった，特に2018年の渴水時は一 時，イスファハン州及びヤズド州の住民 500 万人分 の飲料水確保が困難であると報道されるほどであ り，2018年2月にイスファハンで農民の抗議活動が 発生して以降, 4月下旬まで継続された。また，抗議 活動は次第にエスカレートレ, ザヤンデルード川か らヤズド市への導水管が，イスファハン州の農民ら により破壊される事態が幾度も生じた。 その導水管 の破壊回数は報道で確認する限り, 2018 年 3 月から 10月までの7カ月間で，実に22回に及んだ。

これに対し，ヤズド州はザヤンデルード川の水が 彼らの唯一飲料可能な水源であるとしてその必要性 を訴えるも，イスファハン州農民の理解を得られず にいる，一方で，上流に位置するチャハールマハー ル・バクティアリ州の農民にも不満がたまり, 2018 年4月に抗議行動を行っている。これは，上流部に 位置する同州に降った水や，同州を流れるカルーン 川から流域間導水された水が，イスファハン州のた めに使用されていることへの不満に端を発したもの である。このように，政府による地域間の水の配分 に関する不満が様々な地域で蓄積し，渴水を契機に 導線でつながれたように各地で噴出してきたもので ある。地域的に偏在する水資源に関する地域間配分 の難しさを示す例であると考えられる。

\section{3. 地盤の沈下}

さらに全国的な地下水位の低下は, 様々な地域で 地盤沈下をも引き起こしている。テテラン南部にお いては，地下水位の低下に伴う地盤沈下が生じ, 2013 年には年間 $36 \mathrm{~cm}$ の沈下を記録している。これ

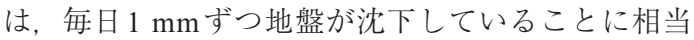
し，極めて大きな地盤沈下であると言える，他の地 域でも地盤沈下が観測されており，エネルギー省作 成資料中の 2005 年データによると, カズビーンで $24 \mathrm{~cm} /$ 年, ケルマーンで $18 \mathrm{~cm} /$ 年, マシュハドで 25 $\mathrm{cm} /$ 年など，イラン国内の主要都市で地盤沈下が記 録され，建築物の壁面の亀裂などの被害が報告され ている。また，広域的な地盤沈下のみならず，局所 的な地盤陥没による被害も発生して打り, 2019年 1 月には局所的な道路陥没によりテへラン市内のバス ルートが変更される事態も生じている.

一方で最近の地盤沈下に関する調查研究に関して は公開されているデータがなく，近年の地盤沈下の 進行や地下鉄や住宅などの構造物への影響について は明確に示されていないため, 地盤沈下が社会的に 
どのような影響を及ぼしているかは明確ではない．

\section{4. 夏季の電力ピーク時の電力不足}

イランでは, 電力ピーク需要に対応するために主 として水力発電（多くの場合は貯水池式）が使用さ れている。一例として, 2017年8月28日のイラン国 内の電力供給の内訳を図一8に示す。これを見ると, 午後の電力消費のピーク時には水力発電による電力 供給が全体の 16.7 \%を占めていることがわかる。し たがって、エネルギーの安定供給の観点からも、イ ランの水資源は非常に重要である.

このため, 非常に厳しい渇水状況下に扔いては, イラン政府が抱く最大の懸念の 1 つは, 夏場の電力 需要ピークへの対応である.このことを 2018 年渇水 時に経験した。

前述の通り 2018 年はイランの過去 50 年以上に及 ぶ統計上 2 番目に降雨の少ない渴水年であった。こ れによりイラン国内の多くのダムで水位が低下し, 夏場の電力需要のピークに対応できない状況が生じ た。このため, イラン政府は, テヘランを含むイラ ン国内の主要都市の地域を分割して計画停電を実施 して電力需要のピークに対応するとともに, テへラ ンの政府系機関については, 約 3 週間にわたり勤務 時間を午前 6 時〜午後 2 時に変更して, 電力需要ピー クの分散を図ることとなった。筆者の勤務する水資 源管理公社においても例外なく, 猛暑の最中に計画 停電及び勤務時間の変更が適応され, 電力の安定供 給のための水資源管理の重要性を認識する機会で あった。

\section{5. 公共水域への污濁物質の流出}

イランに打いては伝統的に, 污水は地下浸透させ て処理してきている。このため, 2017年時点におい ても, 下水道網への接続率は, 都市部では $46 \%$,

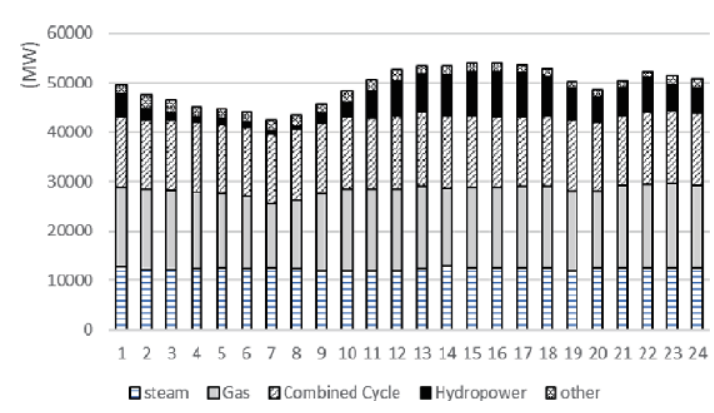

図 -8 2017年 8 月 28 日のイラン国内電力供給内訳

Fig. 8 Breakdown of electricity supply on 28-Aug. 2017.
地方部では $0.4 \%$ と低い水準である. 特に地方部に おいて污水処理率は低く, 公共水域に直接放流され ている場合も多々見られる（写真一2）。これらの課 題に対して浄化槽のような分散型污水処理技術の適 用は有効であると考えるが, イラン国内には污濁物 質を公共水域へ排水することに対する厳しい規制や 取り締まりが行われていないことから, 分散型排水 処理技術に関する行政機関の関心は高い一方で, そ れらを導入するための市場は十分に形成されていな いと感じる.

しかしながら，ホラサン・ラザビ州のカシャフ ルード川では, 生活排水・污水が河川に放流されて, 時期によっては生活排水で河川が満たされ，それら が農業用水として再利用されるなどの水質污染によ る健康被害も生じている事例があり, 政府により不 法占拠者の移住や下水処理施設の建設などの対策が 行われている事例も出てきている.

\section{V ．まとめ}

本稿では, イランが抱える水資源管理に関する現 状や課題を報告した。水資源は, イランの日常生活 を支え, 社会経済活動の土台となるものであり, 極 めて重要な要素である。このため, イランの水資源 に関する危機的な状況や節水の重要性について, 新 聞報道等で報じられることをよく目にするが, 一方 で, 日常生活においてはその深刻な現状を肌で感じ ることは少ない.これは, 1 つには多少の渴水状況で あれば, 地下水の汲み上げ量を一時的に増やすこと で倰げるため, 特に都市部では日常生活に深刻な支 障が生じることが稀なためであると考えられる。ま た，水資源の現状や課題に関する情報は，政府によ

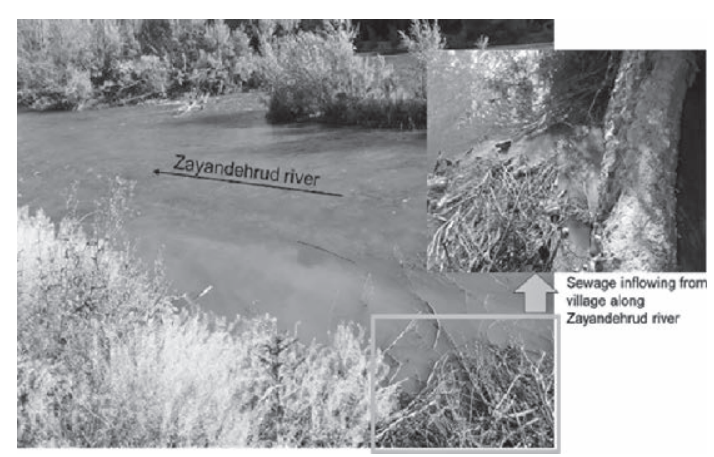

写真 -2 ザヤンデルード川へ流入する生活排水

Photo. 2 Wastewater inflowing to Zayandehrud river. 
り管理されており，国民が直接触れられる機会が著 しく限られるためでもあると考えられる。実際，水 政策アドバイザーとして勤務した約 2 年間で，観測 データを直接利用できたことは非常に稀であり，表 流水及び地下水の水質データについては一度も見た ことがないほど, データ管理が徹底されている。

このような状況から，本人が気づかない間に病状 が進行している内臓疾患を見ているような感覚を覚 える. 地下水の利用が困難なレベルにまで低下した 時が, 内臓疾患が表面化する時期なのかもしれない. イラン内にどれだけの地下水が残されていると推計 されているのか, それは誰も明確にしていない.

イランを取り巻く国際情勢は非常に厳しいものが あり, 水資源の9割を利用している農業生産におい
ても容易に食料自給率を下げるような政策転換は困 難であるだろう。そのような状況下で，持続可能な 地下水利用を含む統合的な水資源管理を行うために は，現在のイランの水資源の現状を「見える化」し て，国民に対する説明責任を果たしつつ，将来にわ たり維持すべき貴重な資源である水を如何に有効か つ持続可能に利用していくかを国民とともに考え， 現実的な行動に移していく必要があると考えてお り，イランの技術者の方々と日々議論を行っている.

\section{引用文献}

\section{国土交通省水管理·国土保全局水資源部 2019. “平成30年版 日 本の水資源の現況”。}

(受付：2019年5月 7 日, 受理：2019年 8 月 8 日)

Iran lies in an arid/semi-arid region of the Middle East. The Iranian hydrological statistics from 1968 show that the 50-year average annual precipitation was, earlier, approximately $248 \mathrm{~mm}$, but has gradually decreased to 220 $\mathrm{mm}$ over the most recent decade, thus, by almost $11 \%$; water resources have fallen nationwide. The Iranian population has grown from less than 30 million in the 1950s to more than 80 million in 2019. Furthermore, urbanization and agricultural development have placed increasing demands on water resources; these activities today account for $86 \%$ of annual water usage. Iran currently experiences extreme water stress. Permanent rivers have gradually become seasonal; the groundwater level has decreased nationwide. Therefore, water resource management is critical in terms of the stability and sustainability of future socioeconomic activities. Here, I describe the challenges faced by those who seek to manage Iranian water resources.

Key words : Iran, water resource, drought, water infrastructure, local conflict 